Dept. of Forensic Medicine and Toxicology, Faculty of Vet. Medicine, Assiut University, Head of Dept. Prof. Dr. A.A. Shaaban.

\title{
IMMUNOTOXIC EFFECTS OF SODIUM FLUORIDE IN CHICKENS
}

\author{
(With 8 Tables and 9 Figures)
}

\section{By}

\section{ABD EL-NASSER; A.SH. SEDDEK; AHLAM ABDEL-HAMID* AND I. EL-SAEDY*}

(Received at 14/10/1995)

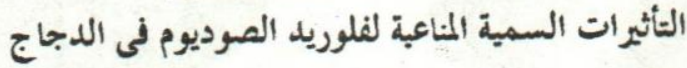

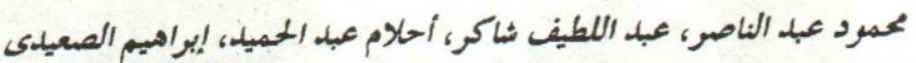

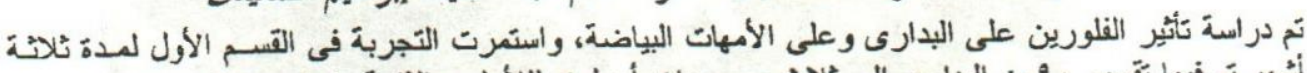

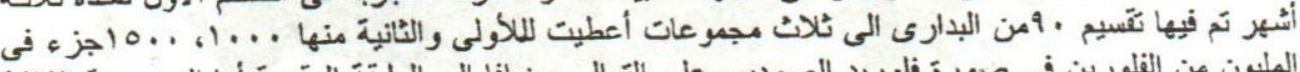

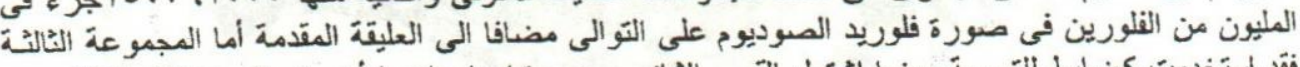

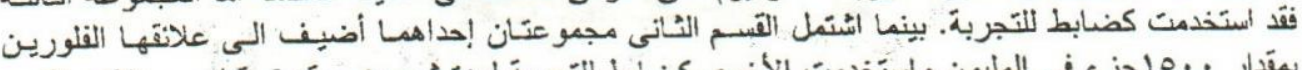

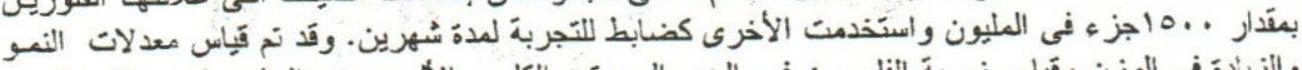

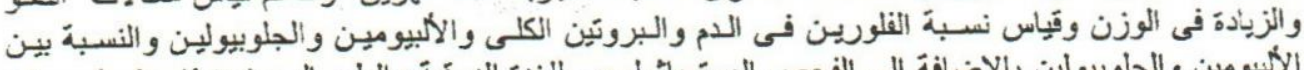

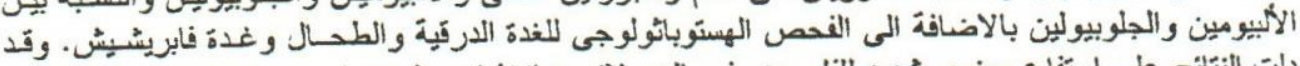

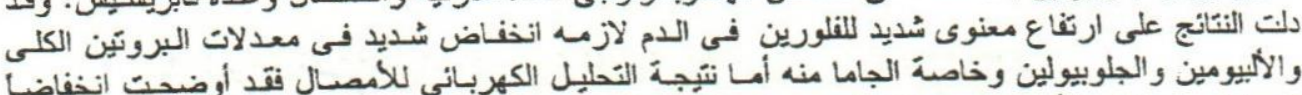

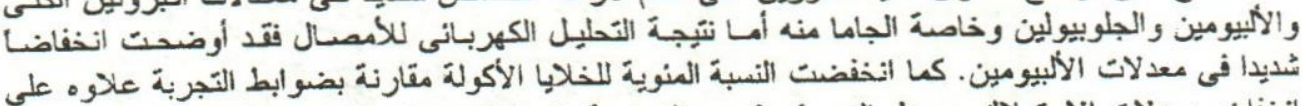

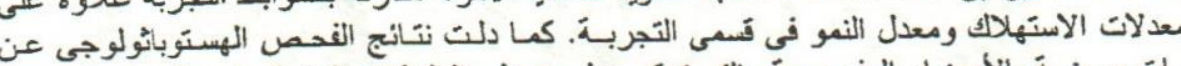

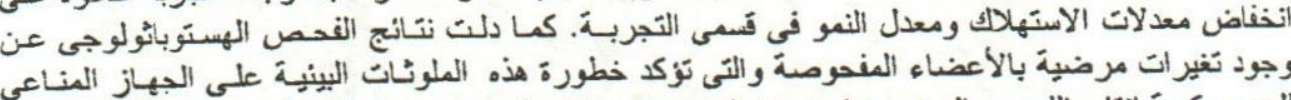

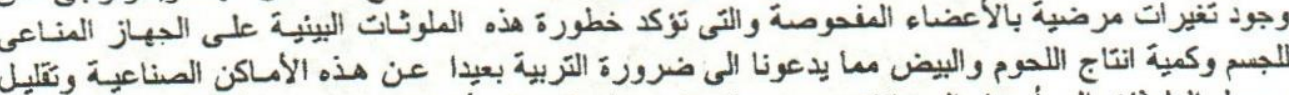

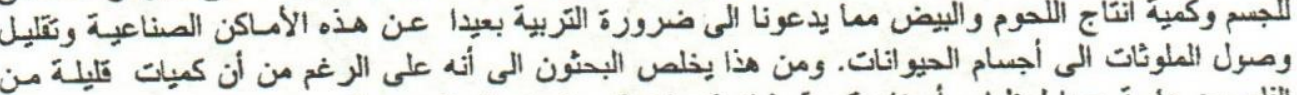

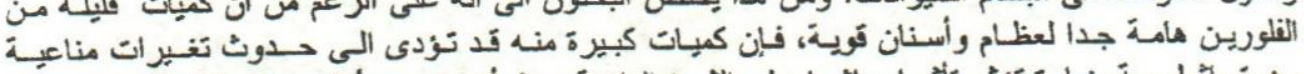

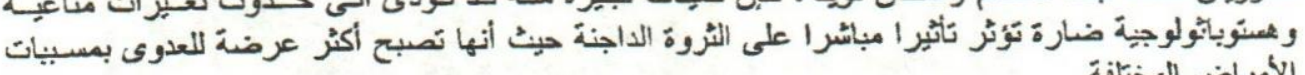

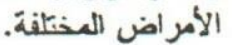

\section{SUMMARY}

The major goal of this investigation is to determine the immunotoxic effects of sodium fluoride $(\mathrm{NaF})$ in chickens. Two experiments were conducted to achieve this goal. In the first experiment, two groups of baiady chickens were exposed to two doses (1000 and $1500 \mathrm{ppm}$ ) of $\mathrm{NaF}$ and third group served as control for three months. In the second experiment, two groups of white high line laying hens were also used, The first group was treated with $1500 \mathrm{ppm} \mathrm{NaF}$ and the second was kept as control for two months. Relative weight of lymphoid organs as well as phagocytosis percentage were

*: Institute of Animal Health Research, Giza, Egypt. 

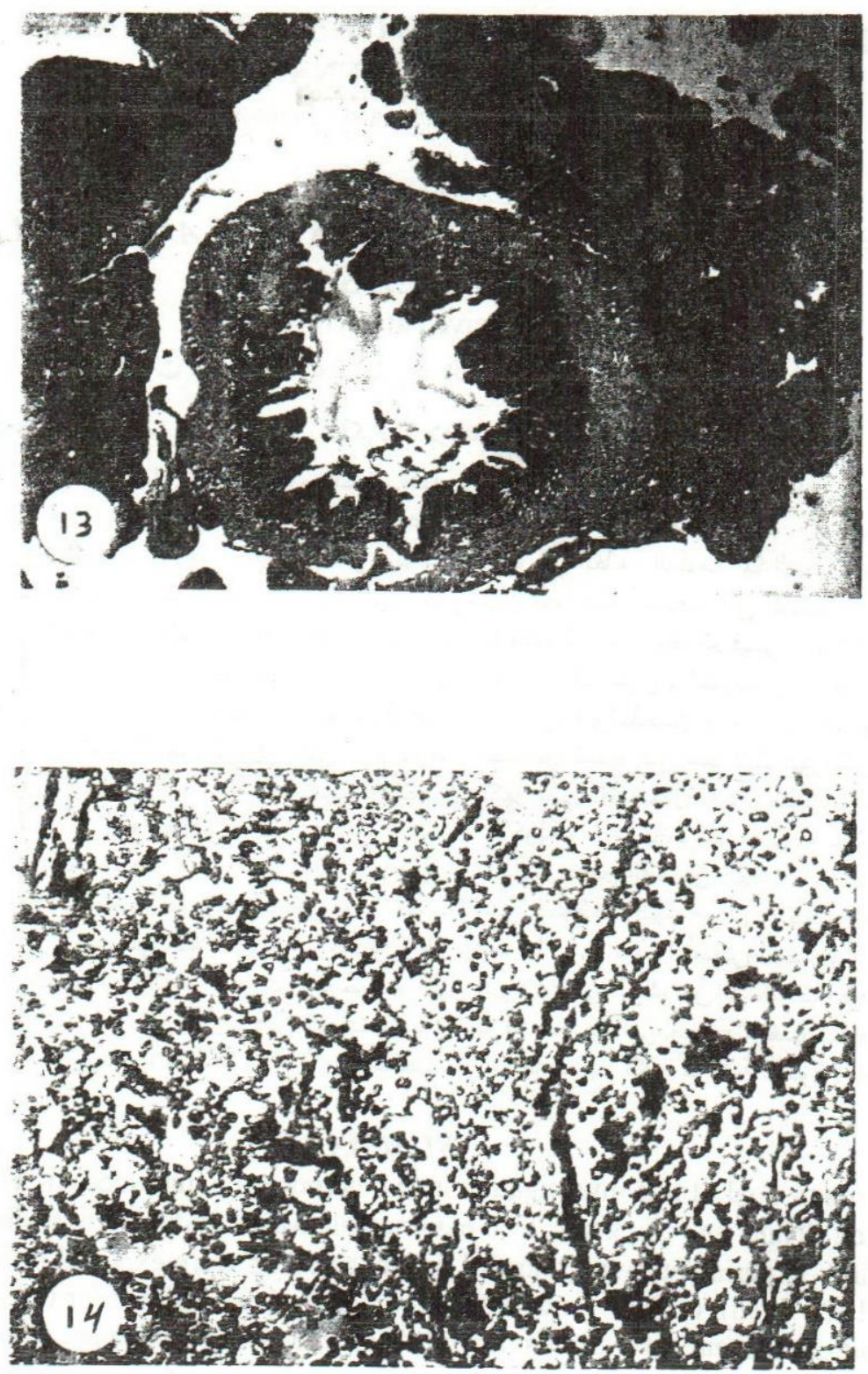
measured 30, 60 and 90 days after exposure of broiler chicken to $\mathrm{NaF}$ and 30 and 60 days in case of laying hens. Body weight and body weight gain were also taken into consideration in both experiments. Significant reduction in the relative weight of both thymus and bursa of fabricius in all chickens exposed to NaF was observed. Phagocytosis percentage was decreased parallely to the weight reduction of thymus and bursa of fabricius. Body weight and body weight gain were significantly decreased allover the course of the experiment in the two doses as well as the two experiments. Total serum protein level, albumin, globulin and $\mathrm{Al} / \mathrm{gl}$ ratio were also reduced with the administration of $\mathrm{NaF}$. The reduction of serum albumin and globulin was positively correlated with the dose and time. Electrophoretic pattern of the tested chickens sera revealed a significant decrease in serum albumin percentrage in the group of chicken's treated with $1000 \mathrm{ppm} \mathrm{NaF}$. Significant disturbances $(\mathrm{P}<0.01)$ were observed in serum globulin fractions IgM, IgA and IgG in our results. Fluoride levels in the serum of tested chickens increased with the increase of the dose and time. Histopathological description of lymphoid organs in treated chickens revealed severe to moderate pathological changes especially with the large dose of $\mathrm{NaF}$ after long time of exposure. Most disturbances caused by the fluoride exposure were dose and time related.

Keywords: Immunotoxicity-sodium fluoride-chickens-electrophoresis

\section{INTRODUCTION}

Some experimental studies on certain animals, and a few studies concerned with the sensitivity of some humans to fluorides have reported that fluorides, at normal and elevated drinking water concentrations could cause significant physiological stress as well as pathological conditions (LU $\underline{\text { et }} \underline{a l}$., 1965; COOK, 1973; GODBER, 1973; JOLLY et al., 1973 and SINCLAIR, 1973).

Fluorine, the most reactive halogen, is ubiquitous mainly in the form of inorganic fluoride compounds. The essentiality of trace amounts of fluorine in animal nutrition has been demonstrated MESSER et al., 1972 and SCHWARZ and MILNE, 1972). Interest in the role of fluoride in poultry nutrition arose not from deficiency symptoms but rather from toxicity Assiut Vet. Med. J. Vol. 34 No. 67, October 1995. problems induced by feeding raw rock phosphate as a calcium and phosphorus source (GUENTER and HAHN, 1986).

In the chicken, antibody-mediated immunity is dependent on the normal development of the bursa of fabricius (GLICK, 1970). Chemical interference with the bursa during embryonic development (GLICK and SADLER, 1961; MUELLER et al., 1960 and WARNER et $\underline{\text { al. }}, 1962$ ) or neonatally (GLICK, 1967, 1970,1971; LERMAN and WEIDANZ, 1970; and TOIVANEN et al., 1972) will be reflected in an elimination or reduction in immunoglobulin G (1gG) and antibody production and maturation of plasma cells. Although thousands of different chemicals are currently used in the course of industrial processes as well as medical purposes, investigations dealing with the influence of these chemicals on 
the immune response have so far been very few.

It is the objective of this paper to report the toxic effects of sodium fluoride administration on the immune system as well as some other parameters in chickens.

Histopathological changes in the lymphoid organs as well as phagocytosis percentage were taken into consideration.

\section{MATERIALS and METHODS}

Sixty Balaby broilers and fourty laying hens have been used in this study in two experiments.

\section{Experiment I:}

In this study we have used 90 clinically healthy Balady broilers, vaccinated, free from internal or external parasites, weighing 400-550 g, and aging two months. These chickens were classified into three groups, the first two groups fed on a ration contaning 1000 and $1500 \mathrm{ppm}$ of sodium fluoride for 3 months and the third group was kept as control, each group contained 6 males and 24 females.

\section{Experiment II:}

Fourty apparently healthy, white high line laying hens of six months, weighing from 1.00 to $1.500 \mathrm{~kg}$ were used. Birds were classified into two groups, each of them contained 20 hens ( 4 males and 16 females). The first group fed on a ration containing $1500 \mathrm{ppm}$ of $\mathrm{NaF}$ for two months while the second was used as a control.

Both experiments were conducted in an environmentally controlled daylighted laboratory. Tape water $(0: 0.2$ Assiut Vet. Med. J. Vol. 34 No. 67. October 1995. ppm fluoride) was provided ad libitum. Commertial ration was used in the feeding of birds containing $3.60 \pm$ $0.26 \mathrm{ppm} \mathrm{NaF}$.

\section{Chemicals:}

Sodium fluoride ( $99 \%$ purity) purchased from Aldrich chemical company Ltd.

\section{Sampling:}

Serum samples were taken 1,2 and 3 months after exposure of broilers of the $1_{\text {st }}$ experiment to fluoride in ration for estimation of serum fluoride, total protein, albumin and electrophoretic pattern. Also, 1 and 2 months for laying hens previosuly exposed to $1500 \mathrm{ppm}$ of fluoride in ration (Experiment II) were administered to the same parameters. Birds were sacrificed monthly from the two experiments to examine the histopathological lesions of lymphoid organs.

\section{Methods:}

Fluoride level, total protein and albumin in the sera were determined according to FRY and TAVES (1970), WEICHSELBAUM (1946) and DRUPT (1974) methods respectively. Protein fractions horizontal zone electrophoresis were carried out (SCHALM, 1979).

Macrophages were collected by peritoneal washing with Hank's balanced salt solution (HBSS), which was chilled and contained $5 \mathrm{Uml}^{-1}$ heparin. The viable counts of macrophages were assessed using the trypan blue dye exclusion method in a Neubauer haemocytometer, and total counts were assessed with Turk's solution as described by SINGH et al. (1984). 
The phagocytic activity of peritoneal macrophages was evaluated using sheep red blood cells (SRBC) according to the method of KOLLER et al. (1980), with the modification of RAISUDDIN $\underline{\text { t }} \underline{\text { al. }}$. (1990). One million cells in a fixed volume were spread over a glass microcoverslip $\left(22 \mathrm{~mm}^{2}\right)$ kept in a plastic petridish of $4.0 \mathrm{Cm}$ diameter. The cells were allowed to adhere at $37^{\circ} \mathrm{C}$ for one hour. The nonadherent cells were washed with phosphate-buffered saline(PBS; $\mathrm{PH}$ 7.2) at $37^{\circ} \mathrm{C}$. Washed SRBC were coated with antisheep haemolysin 1: 500 dilution so as to opsonize them at $37^{\circ} \mathrm{C}$ for one hour. Opsonized cells were washed with PBS, and a $1 \%$ suspension was prepared in RPMI-1640 medium. One mililitre of $1 \%$ SRBC was spread over the coverslip on which the macrophages were adhered. These were incubated at $37^{\circ} \mathrm{C}$ for one hour, then washed with PBS. For microscopic examination, cells were stained with Giemsa-Wright stain and examin-ed in oil immersion under a light microscope. A macrophage was considered positive for phagocytosis if two or more SRBC were seen engulfed (Fig. 10). The percent phagocytosis was calculated according to the following formula:

\footnotetext{
Placecytout - Mecrophages ingulfing more then 2 SRBC X 100 Total number of macrophage

Statistical analysis of the obtained data was performed according to the method of KALTON (1967).
}

\section{RESULTS}

The toxic effects of sodium fluoride on the body weight and body weight gain in chickens are summarized in Table 1. Relative weight of thymus and bursa of fabricius as well as phagocytosis percentage are summa-rized in Table 2. Total serum protein, albumin, globulin and albumin/globulin ratio in adult hens exposed to $1500 \mathrm{ppm} \mathrm{NaF}$ in ration for 3 months are presented in Table 3 , Table 4 shows the electophoretic pattern of hens serum after the exposure to $1500 \mathrm{ppm} \mathrm{NaF}$ for 3 months. Fluoride levels in serum of hens exposed to $1500 \mathrm{ppm}$ sodium fluoride for 3 months are presented in Table 5 . Table 6 summarized total serum protein, albumin, globulin levels and albumin/ globulin ratio in broiler chickens exposed to $\mathrm{NaF}$ in ration in a dose of 1000 and $1500 \mathrm{ppm}$. Electrophoresis picture in the serum of brolier chickens exposed to $\mathrm{NaF}$ in a dose of 1000 and $1500 \mathrm{ppm}$ for two months is presented in Table 7. Table 8 summarized the fluoride levels in the serum of broiler hens exposed to 1000 and $1500 \mathrm{ppm} \mathrm{NaF}$ for two months.

Electrophoretic patterns of serum proteins in control, 1000 and $1500 \mathrm{ppm}$ sodium fluoride are presented in Fig. 1, 2 and 3 respectively.

The results of histopathological examination are presented in Fig. 4-9. Thymus gland, spleen and bursa fibrica of chicken given $1000 \mathrm{ppm}$ of fluorine did not show any detectable histopathological changes, only a 
moderate to servere degree of lymphoid exhaustion is observed in the thymus gland from chicken killed after three months. Histopathological changes of moderate degree were observed in the thymus gland from chicken exposed to a dose of $1500 \mathrm{ppm}$ of fluorine and sloughtered after one month. These changes consisted of wide spread small focal areas of hyalinization of the thymic tissue and mild degree of exhaustion of lymphoid tissue. Hemoglobin pigments were observed with the macrophage cells in the area of hyalinization. Spleen and bursa from this group of chicken showed no detectable microscopic changes.

Thymus gland from chicken slaughtered after two months of administration of 1000 and $1500 \mathrm{ppm}$ showed a relatively large area of hyalinization along with a prominent depletion of lymphoid population (Fig. 4 and 5). However, the spleen from this group of chicken showed no detectable histopathological changes. Bursa fibrica from these chicken showed depletion of lymphoid population and the epithelial cells were necrosed or degenerated and byalinized (Fig. 6). Thymus gland from chicken killed after 3 months of adiministration of $1500 \mathrm{ppm}$ of fluorine showed a wide spread destruction of lymphoid element along with hyalinization of the thymic tissue (Fig. 7). Spleen from this group of birds revealed mild depletion of lymphoid cells population along with proliferation of reticuloendothelial system cells (Fig. 9). Bursa fibrica from such birds was completely fibrosed and contained no lymphoid elements (Fig. 8).

\section{DISCUSSION}

In recent reports, several environmental contaminants were shown to be synergistic to infections agents. Many suggestions have been made in the literature to explain the relationship of high fluoride diets to retarded growth of chickens. Our results presented in Table 1 reported a highly significant reduction in body weight and body weight gain in chickens administered 1000 and 1500 ppm sodium fluoride. This reduction seems to be dose and time dependent. MICHEL et al. (1984) reported that fluoride caused a growth inhibition by the restriction of feed consumption which is systemic in nature and independent of any action in the digestive tract. Relative weight of thymus and bursa of fabricius as well as phagocytosis percentage are summarized in Table 2 . The present study showed that sodium fluoride has an obvious effect on thymus body weight ratio with both 1000 and $1500 \mathrm{ppm}$ doses allover the time of the experiment, meanwhile bursal relative weight was affected after 30 days only with $1500 \mathrm{ppm}$ sodium fluoride and after 45 days with the two used doses. Phagocytosis percentage decreased in a dose and time dependent manner. According to DESCOTES (1986), toxicological manifestations in the immune system following chemical exposure may appear as changes in lymphoid organ weights and/or histology. He added that it is essential in any immunotoxicity evaluation to measure the weight of thymus, spleen and peripheral lymph nodes. The decrease in relative weight of thymus 
and bursa in treated groups of chicken could be attributed to the effect of sodium fluoride administration.

Our results presented in table 3 and 6 revealed a highly significant decrease in total protein in treated hens both with 1000 and $1500 \mathrm{ppm} \mathrm{NaF}$, allover the experiment. This decrease in total protein could be attributed to the inhibitory effect of fluoride on protein synthesis which have been proved before by VESCO and COLAMBO (1970). Fluoride inhibits protein synthesis (HOERZ and MCCARTY, 1971; GODCHAUX and ATWOOD, 1976) and the incorporation of radioactive amino acids into protein is reduced in the presence of low concentrations of fluoride HELGELAND, 1976; LIN et al., 1976; HOLLAND, 1979). It has been indicated that this reduced incorporation of precursors may be due to reduced uptake into the cells (HELGELAND, 1977), and fluoride induced reduction in uptake of other substances has been reported by DOST et al. (1977). It has also been reported that fluoride inhibits $\mathrm{Na}^{+}, \mathrm{K}^{+}$- activated ATPase, an enzyme essential for the uptake of amino acids since it is involved in the transport of $\mathrm{Na}^{+}$and $\mathrm{K}^{+}$, which is necessary for active uptake of amino acids (HOLLAND and HONGSLO, 1979). ABDEL-HAMID and DORRA (1993) proved that feeding of broiler chickens on graded levels of fluorine as sodium fluoride resulted in poor growth and feed conversion efficiency, high mortality, disorders of bone formation, decreased relative weights of pituitary, adrenals, heart, liver, spleen, lungs, kidneys and gizzard and changes in intestinal measurements. Their biochemical tests revealed changes in blood composition in the form of low total protein as well as albumin and globulin fractions.

Our results revealed severe reduction in serum albumin levels in treated chickens in comparsion to control group of chickens. Serum albumin/globulin ratio seems to behave in the same manner as it decreases in the treated group to half of control chickens. Albumin/ globulin ratio has been used to aid in interpretation of total protein values (AHLAM et al., 1994). This ratio will remain normal if both protein fractions are uniformly altered and be abnormal if this alteration was in one fraction (ROBERT and KEITH, 1988). As shown in tables 4 and 7 at 1000 and $1500 \mathrm{ppm} \mathrm{NaF}$, the serum IgG level was reduced and IgM level was increased compared to controls. The increase in serum IgM and the decrease in IgG are interesting finings in our result as IgG antiboy synthesis is thought to be more thymus depenent than IgM synthesis. Hence, our results could suggest an impairment in the function of $\mathrm{T}$ helper cells. IgA an IgD were also affected in variable manner during this experiments, meanwhile there was no effect on IgB except in the first month samples in the group of chicken treated with $1500 \mathrm{ppm} \mathrm{NaF}$.

Fluoride levels in the serum of chickens were presented in Tables 5 
and 8 . There was a highly significant increase in fluoride levels in treated hens in comparison to controls. This increase in serum fluoride concentration found to be time and dose dependent in our experiments. There is an accumulation of fluoride in the serum of all animals and GROTH (1975 a, b) has suggested that this is one of the most notable characteristics of fluoride as a pollutant. Thus, serious adverse effects are possible even at low levels of exposure if this persists for lengthy periods of time. In addition, fluorides are known to cause chromosome damage and mutation in animals (ROSE and MARIER, 1977).

In the assessment of immunotoxic action in experimental animals, histopathology of lymphoid organs is a comerstone VOS, 1977; KRAJNC-
FRANKEN et al., 1990; KUPER et al., 1973 and SCHUURMAN et al., 1991). $D E N$ and VOS (1986) and SCHUURMAN et al. (1994) stated that routine histopathology of lymphoid organs is useful in assessing the immunotoxicity of a chemical. Our results of histopathological examination of thymus, spleen, and bursa of fabricius are presented in figs. 4-9. Histopathological changes shown in our experiments were correlated to the other immune responses as well as fluoride concentrations in the serum of affected hens.

It could be finally concluded that the administration of $\mathrm{NaF}$ for 2 to 3 months could alter the immune response and reduce host resistance to infection leading to economic losses in poultry industry.

\section{REFERENCES}

Abdel-Hamid, A.M. an Dorra, T.M. (1993): effect of feedborne fluorine intoxication on broiler chicks performance, biochemistry, physiology and pathology. Archives of Animal Nutrition, 42 (2): 133-145. Ahlam, A.-H.; Seddek, A.Sh. and Ibrahim, Th.A. (1994): Picture of endemic fluorosis in hens. Vet. Med. J., Gizza, Vol. 42, No. 1: 295-304.

Cook, H.A. (1973): Fluoride toxicity. Lancet ii, 1026-1028.

Dean, J. H. and Vos, J.G. (1986): An introduction to immunotoxicology assessment, In: Immunotoxicology of Drugs and chemicals. Elsevier, Amesterdam- New York, Oxford. 1st edition.pp. 7-10.

Descotes, J. (1986): Immunotoxicology of Drugs and Chemicals. Elsevier Science Publishers 1rg edition, chapter 1.pp. 3-17.

Dost, F.N.; Knaus, R.M.; Johnson, D.E. and Wang, C.H. (1977): Fluoride impairment of glucose utilization: Nature of effect in rats during and after continous $\mathrm{NaF}$ infusion: Toxicol. Appl. Pharmacol. 41: 451-458.

Drupt, F. (1974): Determination of serum albumin. Pharm. Biol., Vol. 9: 77-79.

Fry, B.W. and Taves, D.R. (1970): Serum fluoride analysis with the fluoride electrodes. J. Lab.\& Clinic. Med., 75: 1020-1025.

Glick, B. (1967): Antibody and gland studies in cortisone and ACTH-injected birds. J. Immun. 98: 1076-1084. 
Glick, B. (1970): Immunity studies in testosterone propionate injected chicks. Int. Arch. Allergy, 38: 93-103.

Glick, B. (1971): Morphological changes and humoral immunity in cyclophosphomidetreated chicks. Transplantation, 11: 433-439.

Glick, B. and Sadler, C.R. (1961): The elimination of the bursa of fabricius and reduction of antibody production in birds from eggs dipped in hormone solutions. Poultry science, 40: 185-189.

Godber, G.H. (1973): Fluoride toxicity, Lancet ii, 1217-1218.

Godchaux, W. and Atwood, K.C. (1976): Structure and function of initiation complexes which accumulate during inhibition of protein synthesis by fluoride ion. j. Biol. Chem. 251-301.

Groth, E. (1975 a): Fluoride pollution. Environment 17: 1063-1065.

Groth, E. (1975 b): An evaluation of the potential for ecological damage by chronic low-level environmental pollution by fluoride. Fluoride 8: 224-228.

Guenter, W. and Hahn, H.B. (1986): Fluoride toxicity and laying hen performance. Poultry Science, 63: 769-778.

Helgeland, K. (1976): Effect of fluoride on protein and collagen biosynthesis in rabbit dental pulp in vitro. Scand. J. Dent. Res., 84:276-285.

Helgeland, $K$. (1977): $\mathrm{pH}$ and the effect of fluoride and zinc on protein and collagen biosynthesis in rabbit dental pulp in vitro. Scand. J. Dent Res. 85: 407-413.

Hoerz, W. and McCarty, K.S. (1971): Initiation of protein synthesis in a rabbit reticulocyte lysate system. Biocheim. Biphys. Acta, 228: 526-535.

Holland, R.I. (1977): Fluoride inhibition of protein and DNA synthesis in cells in vitro. Acta pharmacol. et Toxicol. 32: 21-60.

Holland, R.I. and Hongslo, J.K. (1979): The effect of fluoride on the cellular uptake and pool of amino acids. Acta Pharmacol. et Toxicol., 44: 354-358.

Jolly, S.S.; Parasad, S.R.; Sharma, R. and Chander, R. (1973): Fluoride poisoning in punjab. Fluoride, 6: 4-10.

Kalton, G. (1967): In: "introduction to statistical ideas from social scientists". 2nd Ed. Acad. press (London).

Koller, L.D.; Roan, J.G. and Brouner, J.A. (1980): Methyl mercury effects on Blymphocyte receptors and phagocytosis of macrophages. J. Environ. Pathol. Toxicol. 3: 407-411.

Krajnc-Franken, M.A.; Van Loveren, H.; Schuurman, H.J. and Vos, J.G. (1990): The immune system as a target for toxicity: A tiered approach of testing with special emphasis on histopathology. In: A.D. Dayan; R.F. Hertel; El Heseltine; G. Kazantis; E.M. Smith and M.T. Van der Venne (Eds), Immunotoxicity of metals and immunotoxicology, Plenum press, New York, P. 241-271. 
Kuper, C.F.; Schurman, H.-J. and Vos, J.G. (1993): Pathology in immunotoxicology. In: G. Burleson; A. Munson and J. Dean (Eds), Modern methods in immunotoxicology, Wiley, New York, p. 332-349.

Lerman, S.P. and Weidanz, W. (1970): The effect of cyclophosphamide on the ontogeny of the humoral immune response in chickens. J. Immunol. 105: 614619.

Lin. B.J.; Henderson, M.J.; Levine, B.B.; Nagy, B.R. and Nagy, E.M. (1976): Effect of iodoacatate and fluoride on islet respiration and insulin biosynthesis. Horm. Metab. Res., 8: 353-358.

Lu, F.C.; Grewal, R.S.; Rice, H.B.; Graham, R.C. and Allmark, M.G. (1965): Acute toxicity of sodium fluoride for rhesus monkeys and other laboratory animals. Acta pharmac. Tox., 22: 99-106.

Messer, H.H.; Armstrong, W.D. and Linger, L.A. (1972): Fertility impairment in mice on a low fluoride intake. Science 177:893-894.

Michel, J.N.; Suttie, J.W. and Sunde, M.L. (1984): Fluorine deposition in bone as releted to physiological state. Poultry Science 63: 1407-1411.

Mueller, A.P.; Wolfe, H.P. and Meyer, R.K. (1960): Precipitin production in chickens. XXI. Antibody production in bursectomized chickens and in chickens injected with 19-nortestesterone on the fifth day of incubation. J. Immunol. 85: 172179.

Raisuddin, K.P.; Singh, S.I.; Zoidi, A.; Saxena, A.K. and Ray, P.K. (1990): Effects of aflatoxin on lymphoid cells of weanling rat. Journal of Applied Toxicology, Vol. 10(4): 245-250.

Robert, J.D and Keith, W.P. (1988):Veterinary Laboratory Medicine. 2nd edithion. Laboratory Congress Cataloging in Publication data.p. 403-409.

Rose, D. and Marier, J.R. (1977): Environmental Fluoride National Research Council, Canada, NRCC No. 16081. Ottawa, p. 151-155.

Schalm, O.W. (1979): Veterinary Haematology. 4th Ed. Lea \& Fabiger Philadelphia. p. 213-217.

Schuurman, H,-J.; Krajnc-Franken, M.A.; Kuper, C.F.; Van Loveren, H. and Vos, J.G. (1991): Immune system. In: W.M. Haschek and C.G. Rousseaux (Eds), Handbook of toxicologic pathology, Academic press, San Diego, p. 421-453.

Schuurman, H.-J.; Kuper, C.F. and Vos, J.G. (1994): Histopathology of the immune system as a tool to asses immunotoxicity. Toxicology $86: 187-212$.

Schwarz, K.M. and Milne, D.B. (1972): Fluoride regiment for growth in rats. Bioinorg. Chem. 1: 331-334.

Sinclair, H. (1973): Fluoride toxicity. Lancet ii, 1962-1965.

Singh, K.P.; Saxens, A.K.; Srivastava, S.N. and Shanker, R. (1984): Effect of caffeine (1, 3, 7-trimethylxanthine) on bone marrow cells of mice.Indian J. Exp. Biol., 22: 608-611. 
Toivanen, P.; Toivanen, A.; Linna, T.J. and Good R.A. (1972): Ontogeny of bursal function in chickens. II-Post embryonic stem cell for humoral immunity. J. Immunol. 109: 1071-1080.

Vesco, C. and Colambo, B. (1970): Effect of sodium fluoride on protein synthesis in Hella cells Inhibition of ribosome dissociation. J. Mal. Biol., 47: 335-352.

Vos, J.G. (1977): Immune suppression as related to toxicology. CRC Crit. Rev. Toxicol. Suppl., 4: 95-103.

Warner, N.L.; Szenberg, A.A. and Burnet, F.M. (1962): The immunological role of different lymphoid organs in the chicken. I-Dissociation of immunological responsiveness. Aust. J. Exp. Biol., 40: 373-388.

Weichselbaum, P.E. (1946): Determination of total serum protein. Am.J. Clin. Path., 16: $40-42$. 


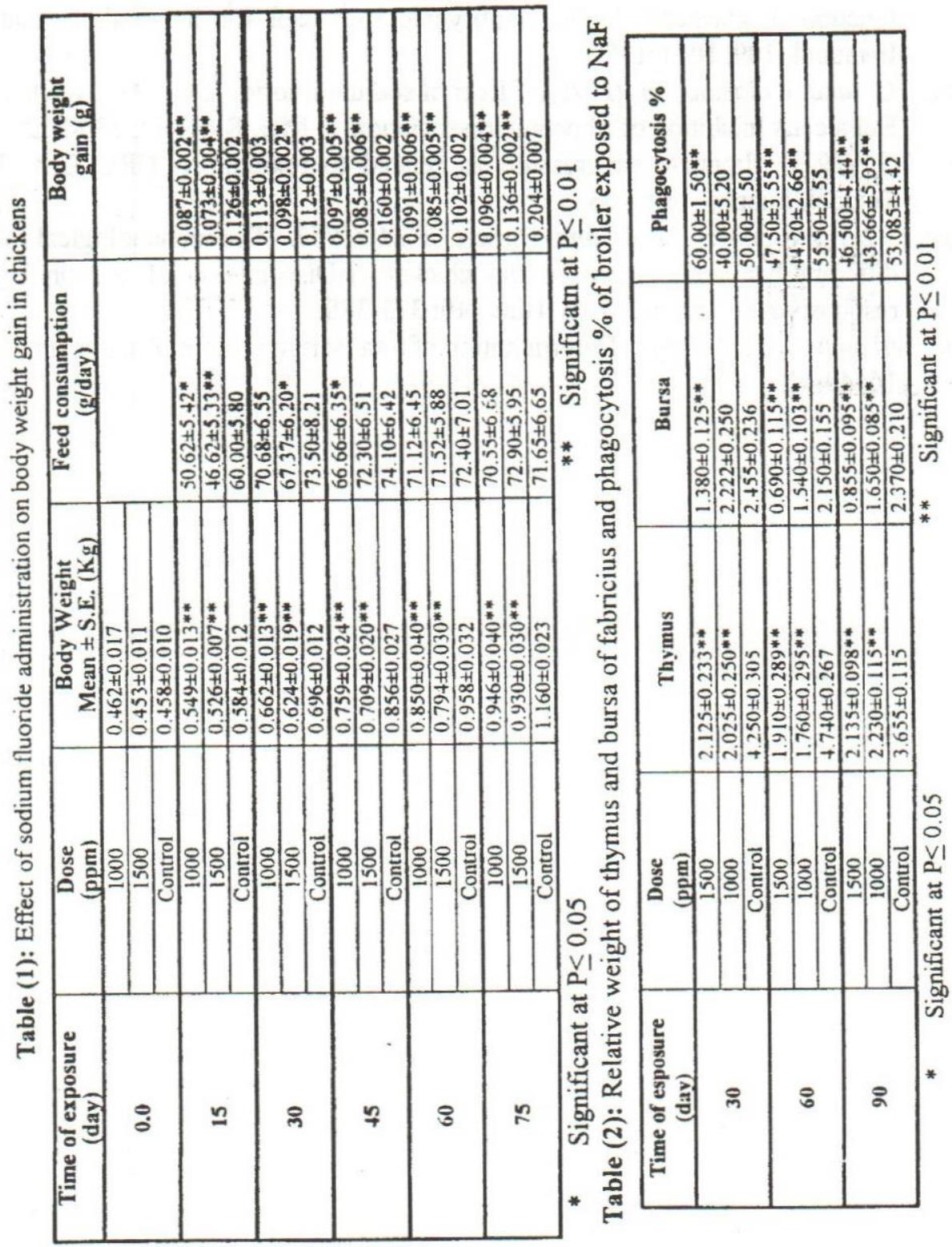




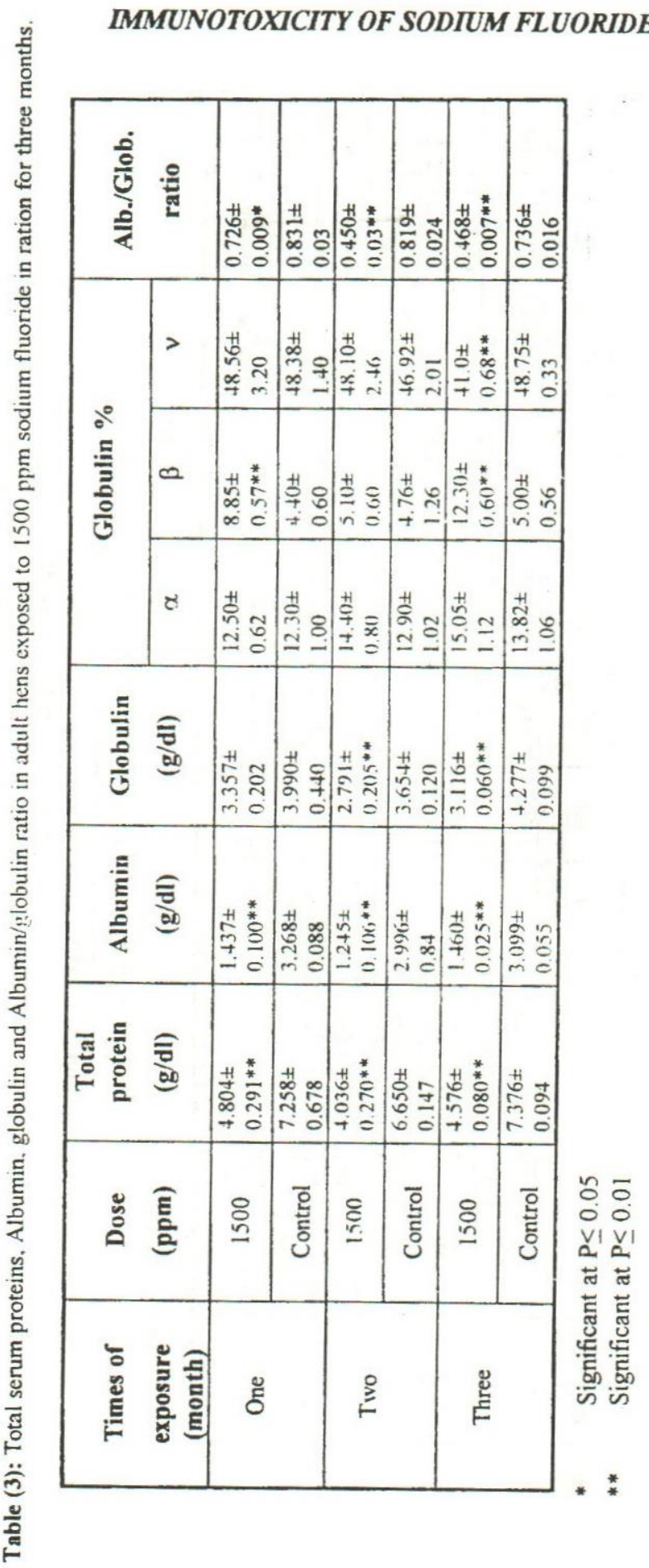




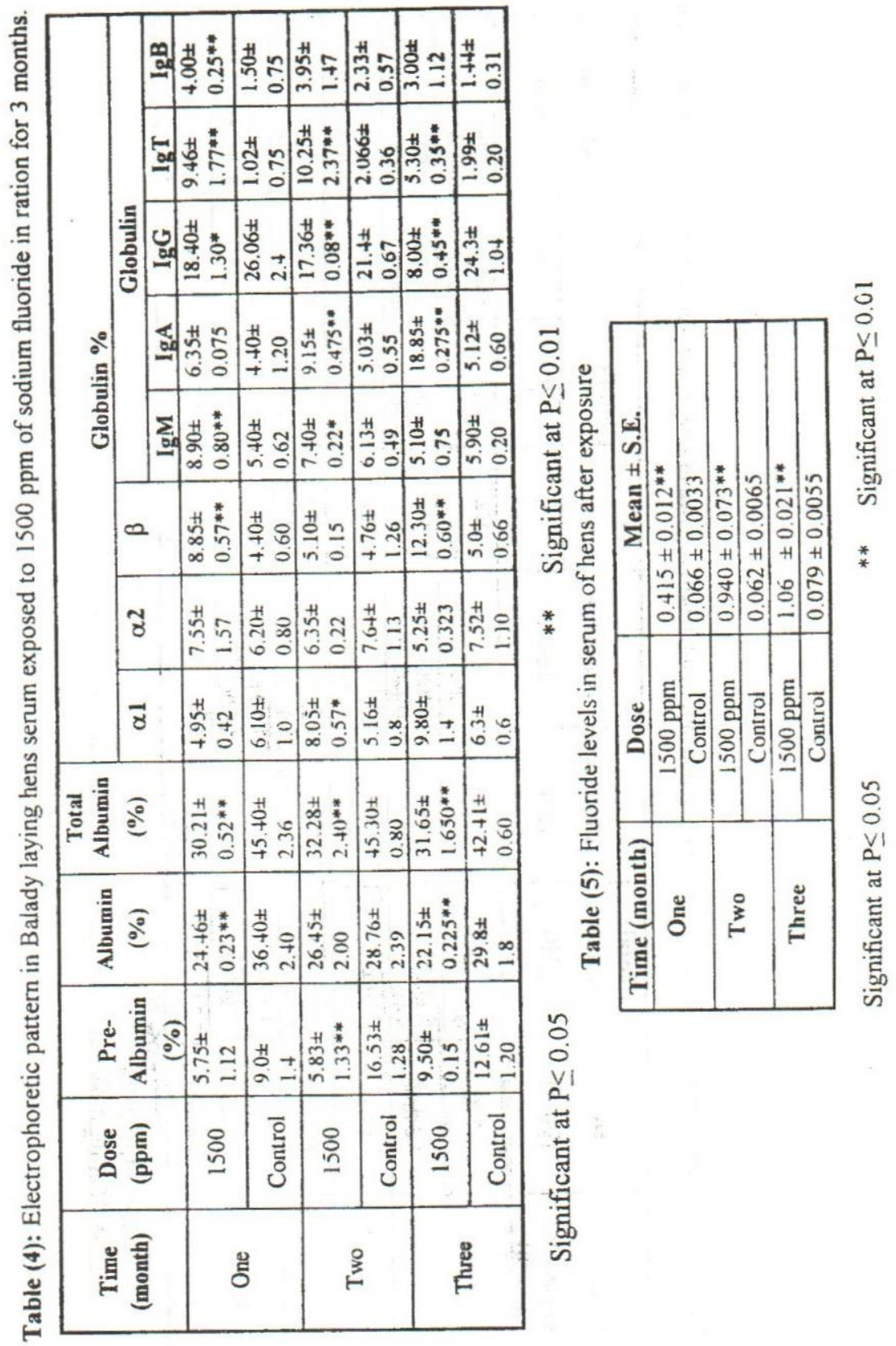




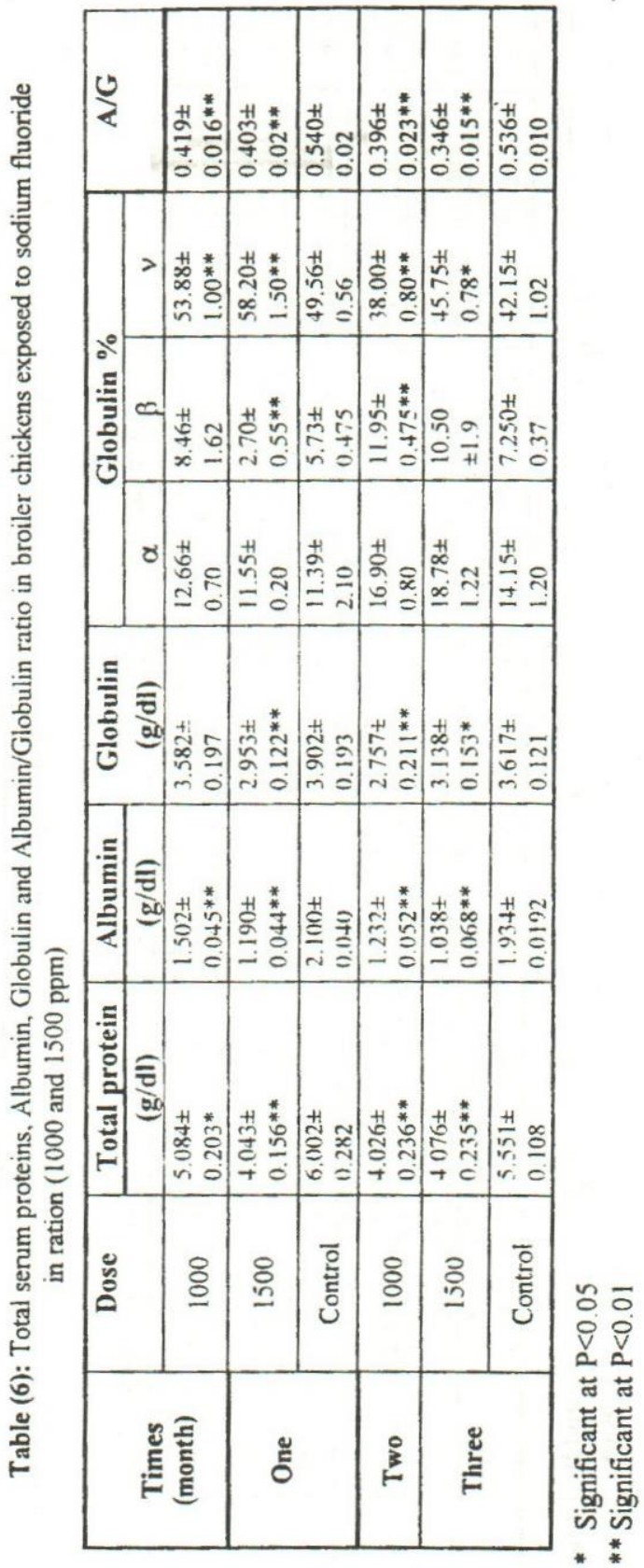




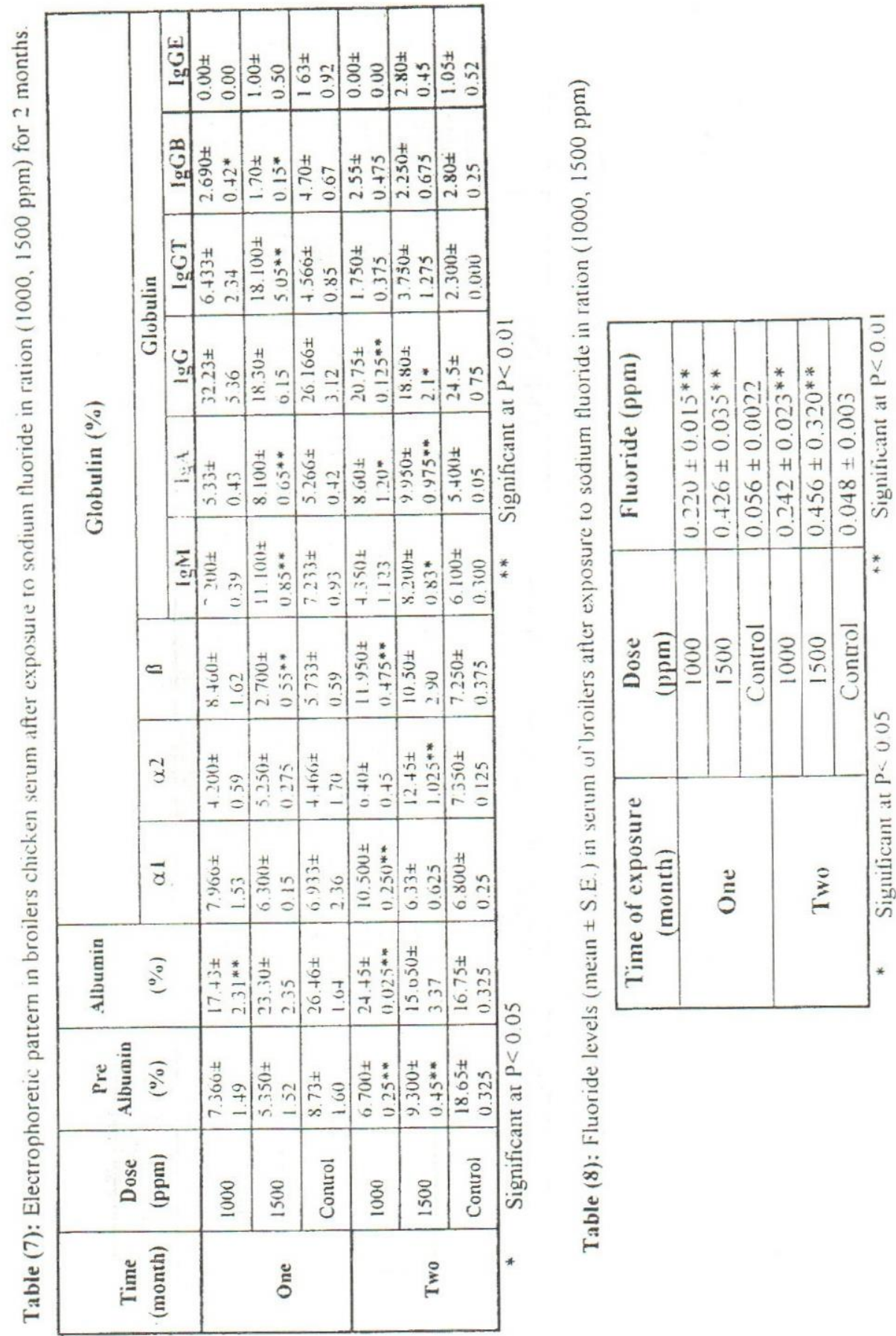




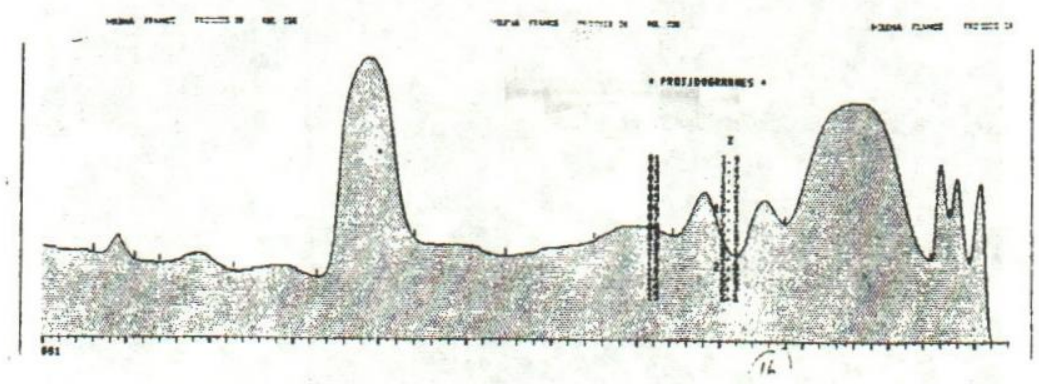

Fig. 1: Electrophoretic pattern of control serum

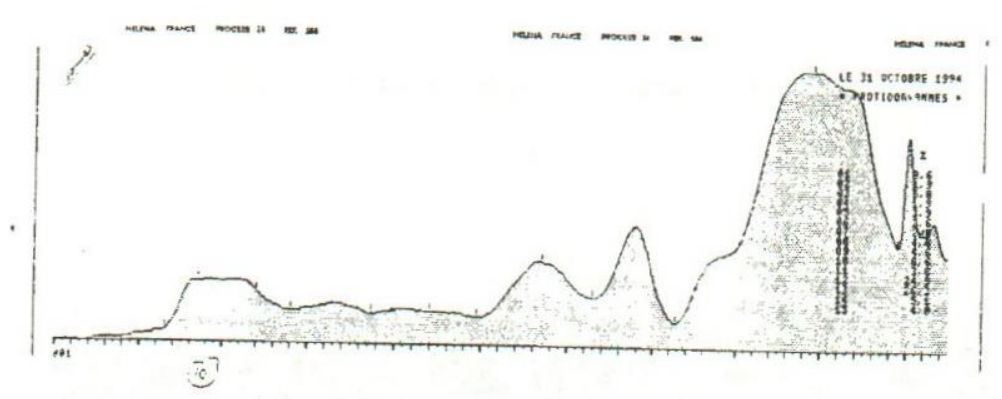

Fig. 2: Electrophoretic pattern of serum after $1000 \mathrm{ppm} \mathrm{NaF}$

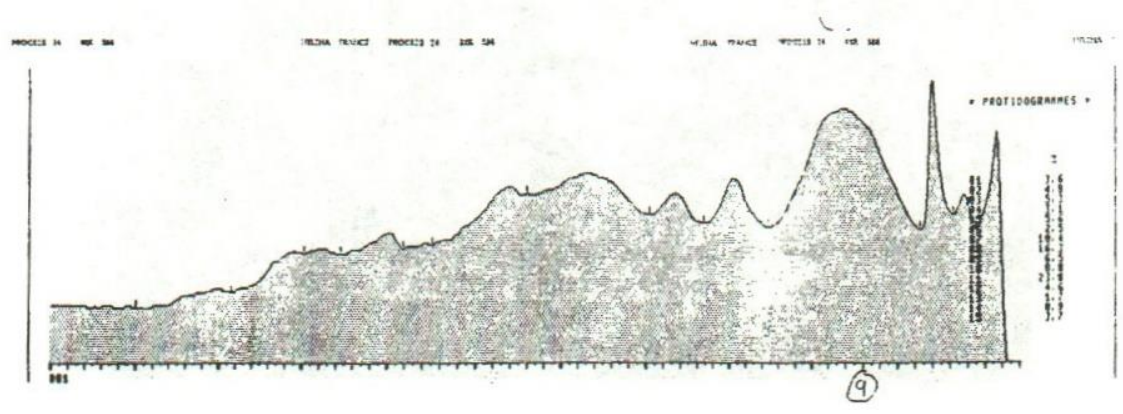

Fig. 3: Electrophoretic pattern of serum after $1500 \mathrm{ppm} \mathrm{NaF}$ 


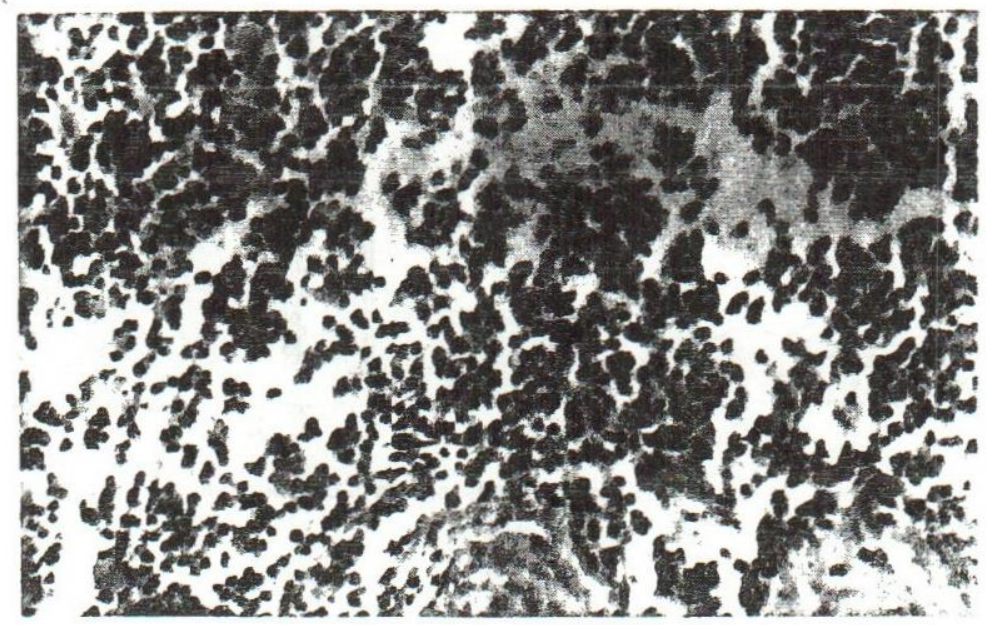

Fig. 4: $1000 \mathrm{ppm} \mathrm{NaF}$ after 3 months: depletion of lymphoid population of thymus gland. H \& E stain (25X)

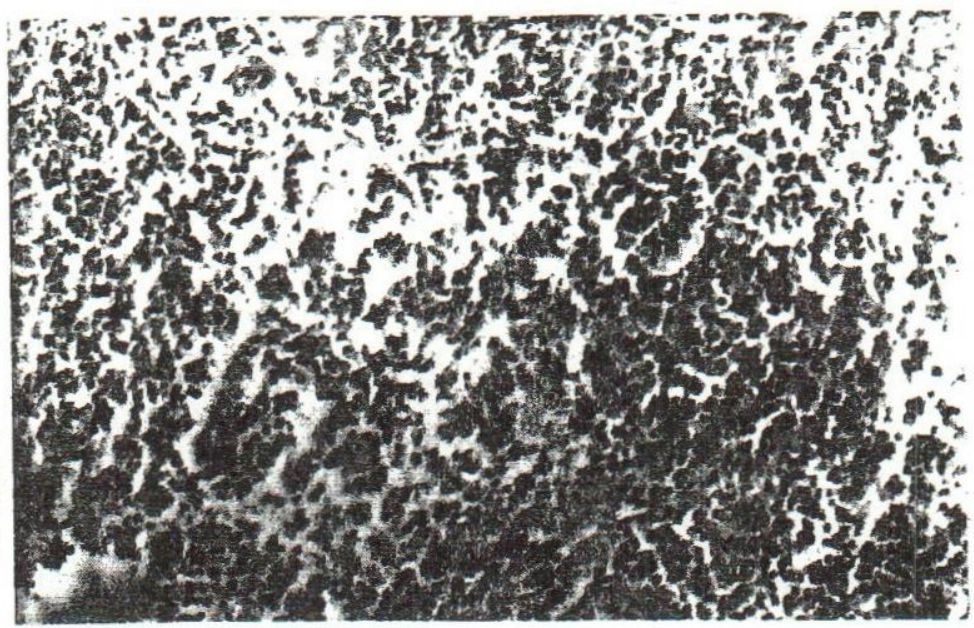

Fig. 5: $1500 \mathrm{ppm} \mathrm{NaF}$ afier 2 months: severe degree of depletion of lymphoid population. H \& E stain (10X) 


\section{IMMUNOTOXICITY OF SODIUM FLUORIDE}

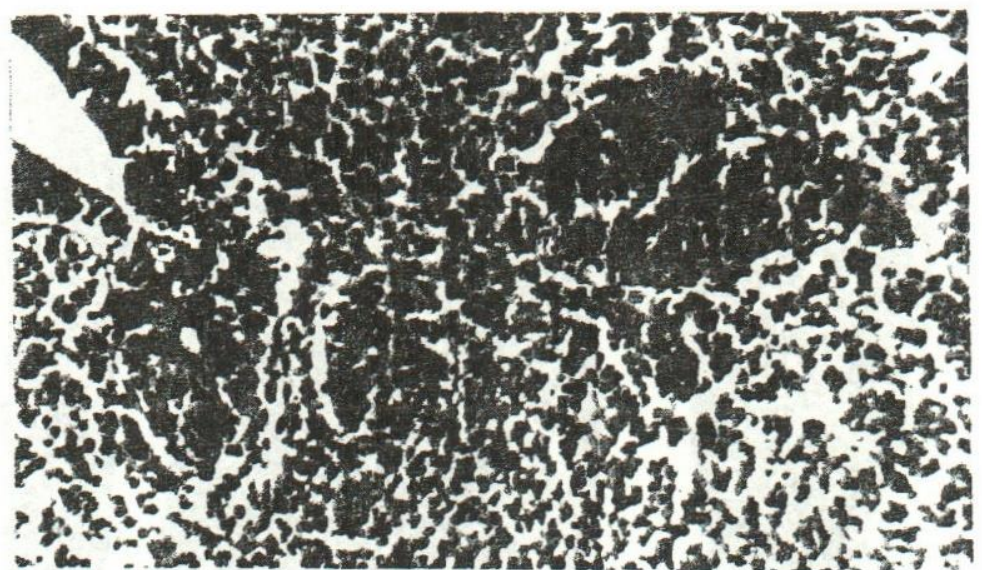

Fin. 6: $1500 \mathrm{ppm} \mathrm{NaF}$ after 2 months: depletion of tymphoid tissue in the bursa with necrosis and hyalinization of the epithiliun $H \& E$ stain (1UX)

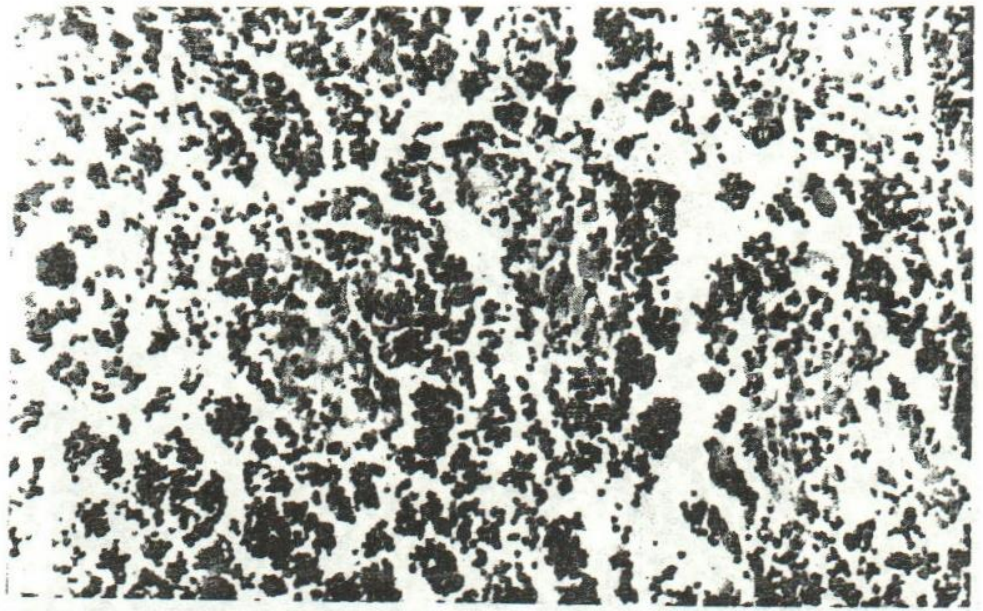

Fiz. 7: $1500 \mathrm{ppm} \mathrm{NaF}$ after 3 months: severe exhaustion of Iymphoid population and hyalinization of thymic tissue H\&E stain $(10 \times)$ 

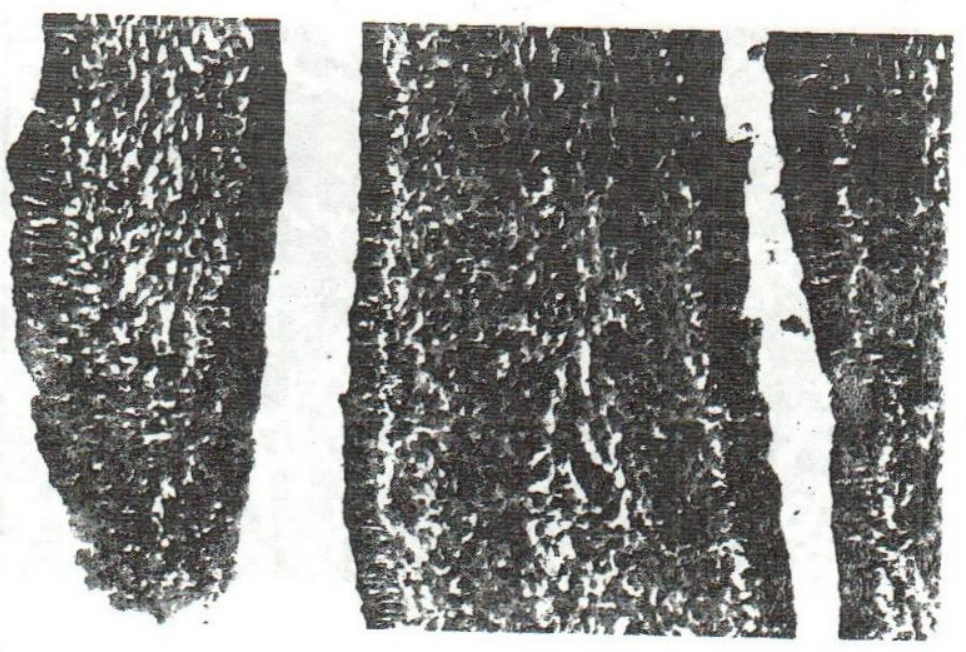

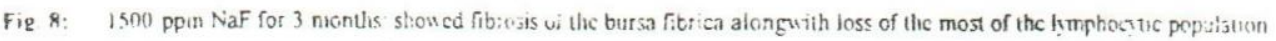
H\&E stain $(X)(1)$

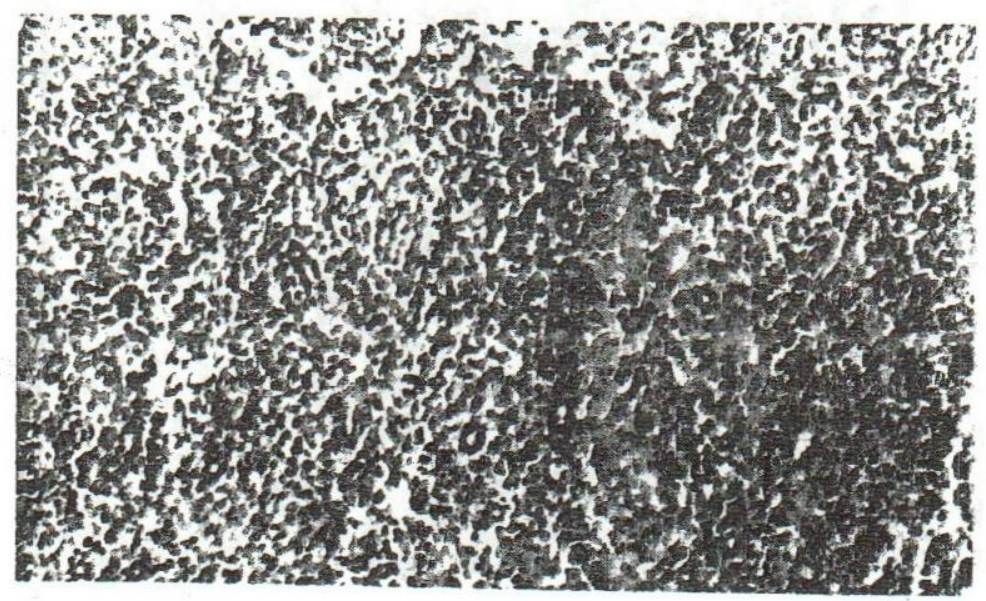

Fig. 9: $\quad 1500$ ppm NaF for 3 months: spiecn shewed mild deplation of lymphoid cells population along wuth proliferation of the raticulecndothcial cclis H\&E stain (10X) 